大腸全摘・回腸肛門吻合術々後にみられた偽膜性腸炎の 1 例

\begin{tabular}{|c|c|c|c|c|}
\hline \multicolumn{5}{|c|}{ 久留米大学第 1 外科 } \\
\hline 敏生 & 音琴要一郎 & 疋田 & 土田 & 勇 \\
\hline 康弘 & 光男 & 梶原賢一郎 & 小野 & 真一 \\
\hline 啓介 & 磯本 & 山内 & 掛川 & 暉夫 \\
\hline
\end{tabular}

\title{
PSEUDOMEMBRANOUS COLITIS AFTER PROCTOCOLECTOMY WITH ILEAL RESURVOIR AND ILEOANAL ANASTOMOSIS FOR THE ULCERATIVE COLITIS PATIENT
}

\author{
Toshio KOBATAKE, Yoichiro NEGOTO, Shigeki HIKITA, \\ Isamu TSUCHIDA, Yasuhiro OOMORI, Mitsuo SOU, \\ Kenichiro KAJIWARA, Shinichi ONO, Keisuke HAYASHIDA, \\ Hiroharu ISOMOTO, Yutaka YAMAUCHI and Teruo KAKEGAWA
}

The First Department of Surgery, Kurume University School of Medicine

索引用語：潰瘍性大腸炎, 回腸肛門吻合術，偽膜性腸炎

I.はじめに

偽膜性腸炎は主として抗生剂投与による腸管内フ ローラの変動により, Clostridium difficile の異常増殖 を引き起こした結果，それより産生された toxinの作 用で腸管粘膜に炎症が生じたものとされている。

われわれは潰愓性大腸炎症例に対する大腸全摘術後 にS 字型詝溜囊付回腸肛門吻合術を行ったところ, 術 後眝溜䒼内に留置した減圧 Draine の拔去之時を同じ くして発熱および著しい腹痛を訴え，きわめて大量の 腸内容液の排泄があり，この腸液からClostridium difficileの toxin を認めた症例を経験したので報告す る.

患者：28歳，女性。

$$
\text { II. 症例 }
$$

主訴：下血。

既往歴：特記すべきものなし。

家族歴：祖母が直腸癌で死亡.

経過：昭和 56 年第 2 子出産前後から下痢, 腹痛が出 現, 潰瘍性大腸炎の診断にて投薬加療中であった。昭 和56年 7 月 3 日大量下血, toxic megacolonのため当 大学救急救命センターに入院時はショック状態にあり 諸種の保存的治療を行うも止血せず，繄急手術として 結腸全摘, 直腸空置, 回腸瘦造設術を施行した.

10月 3 日退院し以後外来で経過を観察していたが,

$<1986$ 年 5 月 14 日受理 >別刷請求先 : 小畠 敏生

厂 830 久留米市旭町 67 久留米大学医学部第 1 外科
残存直腸の炎症が再燃し出血が次第に増強してきたた め, 二期手術の目的で昭和 57 年 7 月 12 日再入院となっ た.

入院時現症：身長 $160 \mathrm{~cm}$, 体重 $42 \mathrm{~kg}$, 眼瞼結膜に貧 血なし，腹部は平坦で下腹部正中に手術創があり，右 下腹部の回腸人工肛門は粘膜面おょび周囲皮䖉に異常 はなかった。

検査成績：血液性化学検查では血清鉄が $24 \mu \mathrm{g} / \mathrm{ml}$ と低值を示し，肝機能検査でもZTT 18.9, TTT 18.5 （Ku U）と膠質反応の上昇を認めた。

直腸鏡所見：残存直腸は口側盲端むで約 $15 \mathrm{~cm}$, 正常 粘膜は注とんど観察されず，潰愫舀痕部と pseudopolyposis が混在し全体的に易出血性であった。

手術所見扣よび術式：開腹すると空置直腸上縁は promontorium 直下に位置して掞り, 腹膜反転部上䄪 $10 \mathrm{~cm}$ が残存していた。この上縁部より粘膜抜去を試 みたが, 粘膜下層の線維化が予想以上に強いため, 完 全な直腸粘膜の抜去を断念し歯状線直上で直腸切除を 行った. 回腸瘦を切除後, その回腸断端から約 $50 \mathrm{~cm} の$ 回腸を S 字状に重合し S 字型貯溜囊を作成した（図 1). 貯溜囊下縁から末端までの脚の長さは約 $8 \mathrm{~cm}$ と し，歯状線直上で全層一層回腸肛門吻合術を行った。 貯溜囊内には経肛門的に減圧管を留置し固定した。術 後一定期間は intravenous hyperalimentation (IVH) 管理で行い, diverting ileostomyは造設しなかった.

術後経過：術後18日までの経過は順調で発熱もみら れず, 貯溜囊减圧管よりの腸液は 1 日500 600 $\mathrm{ml}$ で暗 
因 1 貯溜晸付回腸肛門吻合術の手順
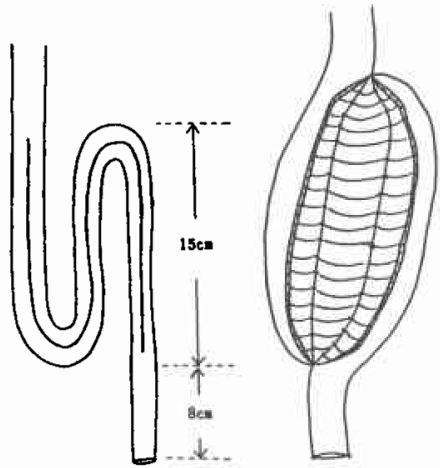

S 状经台する。

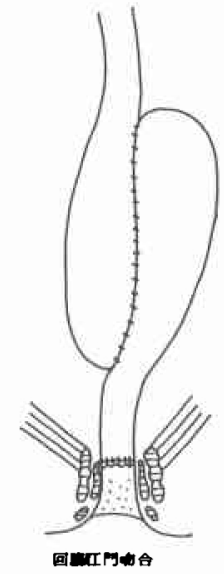

図 2 回腸肛門吻合術から再手術までの経過

術 後 経

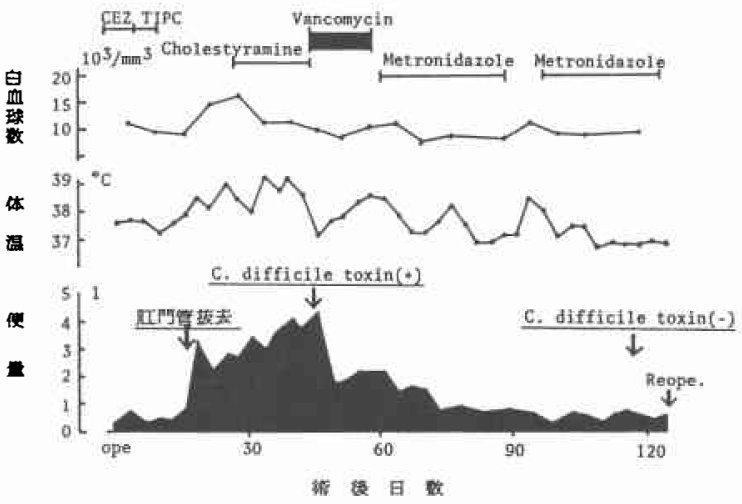

緑色, やや粘調性を呈していた。予防的抗生剂投与は Cefazolin 6 日間, Piperacillin 5 日間の計11日間で中 止した。しかし術後19日経肛門的貯溜囊減圧管が自然 拔去した直後から，強い腹痛をともなった，呕気，呕 吐などのイレウス症状を呈してきた。同時に $38 \sim 39^{\circ} \mathrm{C}$ の発熱がみられ, 白血球数む18,000 増加した。腹部 は緊満し，打診にて鼓音を呈し，聴診では，腸蠕動の 六進を認めた。貯溜囊減圧管を直ちに再留置し, 経鼻 胃管による上部消化管減圧も施行したが諸症状の軽减 はなくむしろ増強傾向にあった，その時再留置された 減圧管からの腸内溶液は 1 日量 $3 l \sim 4 l$ ह, 術直後に比 較して急激に増加し, その性状は淡褐色浆液性を呈し, 静置すると 3 層に分離して観察された（図 2)。

すなわち下 $1 / 4$ には灭白色の壊死物質が沈殿し表層 は豆腐のカス状浮遊物を認め, 中間は褐色水溶性で あった(写真 1$)$. 腹部単純撮影では著明な小腸の拡張
写真 1 大量に排泄された腸液の一部

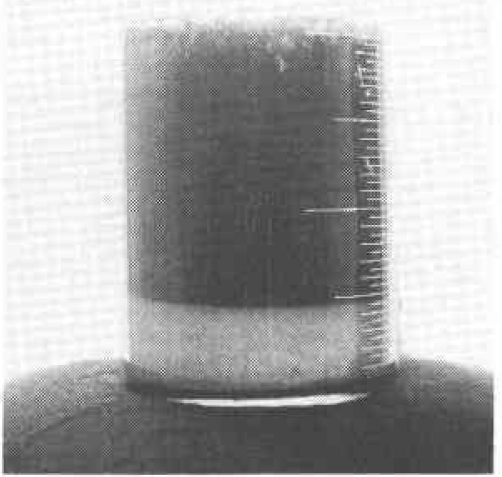

写真 2 腹部単純撮影にて 逆行性貯溜霬造 著明な小腸ガス像を認め 影では辺縁の不 る. 整と瘦孔を認め る.

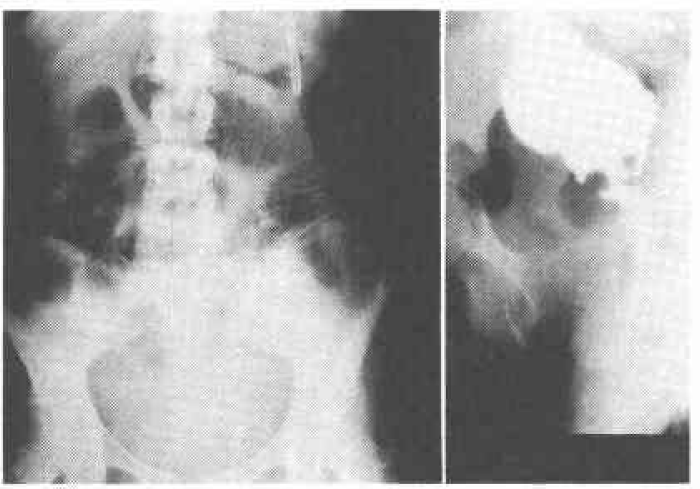

像を認め, 逆行性貯溜囊造影を行らと, 貯溜震は約 150 $\mathrm{ml}$ の造影剂で注注充満され辺縁の不整像と回腸肛門 吻合部より，造影剤の漏れを認めた(写真 2)。この吻 合不全部は胵に瘦孔を形成したため骨盤内に広がるこ とはなかった。

大腸内視鏡検查では，眝溜囊の粘膜面は著明な発赤 と浮腫を認め黄白色の偽膜が多数付着していた（写真 3 右), 貯溜鸾入口部周囲が特に所見が強く，その生検 組織検査においては粘膜面の強い溢血, 腺管の萎縮, 表層びらんを認めるが明らかな偽膜の付着は認めな かった。 また粘膜下層に招よぶ著明な炎症細胞浸潤， 一部 crypt abscess 6認められた（写真 3 左）.

貯溜簧から約 $60 \mathrm{~cm}$ 口側までの観察からも，粘膜面 は浮腫状で粗䊁であったが発赤あるいは潰瘍などは認 めなかった。

以上の所見から偽膜性腸炎を疑い直ちに腸液からの 


\section{写真 3 生検組織所見}

(HE 染色 $\times 80)$. 表

層びらんと粘膜下層 におよぶ炎症細胞浸

潤を認める。

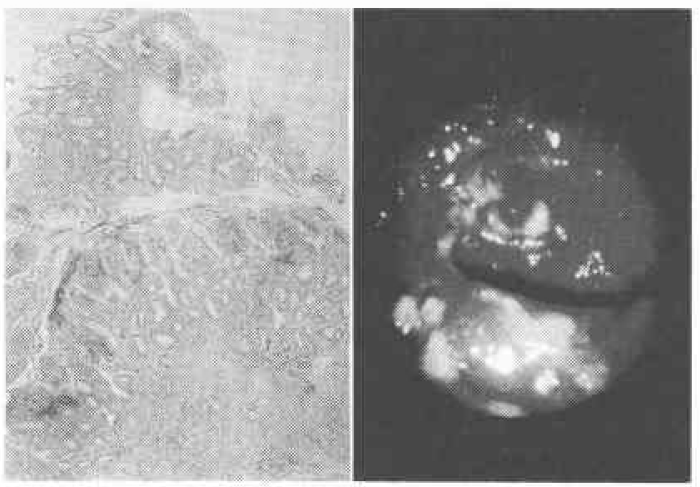

毒素㧍よび菌種同定を行った，検査結果を待つ間にも 発熱および大量腸液排泄が持続するためCholestyr amine resinの経口投与を行い, また脱水, 低蛋白血症 などの予防之治療を兼て IVH および末梢静脈から， プラズマ, アミノ酸液, 糖液, 脂肪乳剂を 1 日総投与 量5 6lで管理したので全身状態は比較的良好に維持 された。腸液からClostridium difficileの菌体分離は できなかったものの大量の Toxin が検出されたため Vancomycin $2 g$ の経口投与を開始した。投与開始後 2 日目ごろから下熱し腸液も著明に減少, 臨床経過は安 定してきたが，投与開始後 7 日に貯溜囊減王管が自然 拔去を機に再び発熱, 腹痛, 呕気が出現した。これら の症状は前回致ど強くはなかったが，減圧管再留置後 も症状は持続しVancomycinの効果もみられなく なった。菌交代現象, あるいはV Vancomycin 耐性之 なったことが考兄られたため Metronidazole に変更 したところ再び症状は軽減した，その後も再三減压管 が抜けることがあり，そのたびに軽度ながら症状の出 現をみた。しかし，Metronidazole 持続投与と減圧管 の持続により症状は消失, 腸内容も次第に暗緑色とな り500 600 ml で安定し経口摄取も可能となった。

この全経過を通じて，減圧管抜去と Metronidazole 中止は症状の再燃をたすこと，ぬた胵瘦の自然閉鎖 も期待できないことなどから,術後126日目の12月16日 再手術を施行した。すなわち貯溜囊切除，自然肛門閉 鎖後, 約 $7 \mathrm{~cm}$ の逆蠕動分節腸管を插入し永久的回腸瘻 を造設した。摘出された貯溜囊に生塩水を注入してそ の容量を計測すると約 $300 \mathrm{ml}$ で充満された。前壁で切 開すると貯溜囊の粘膜面は発赤が強く壁は菲薄になっ ていたが明らかな潰瘍および偽膜は認めなかった。
写真 4 上) 摘出物の新鮮標本写真. 発赤は著明だが 潰瘍・偽膜は認めない，下）同組織所見 (HE 染色 $\times$ 80)。粘膜下層に扔よぶ炎症細胞浸潤が著明である。

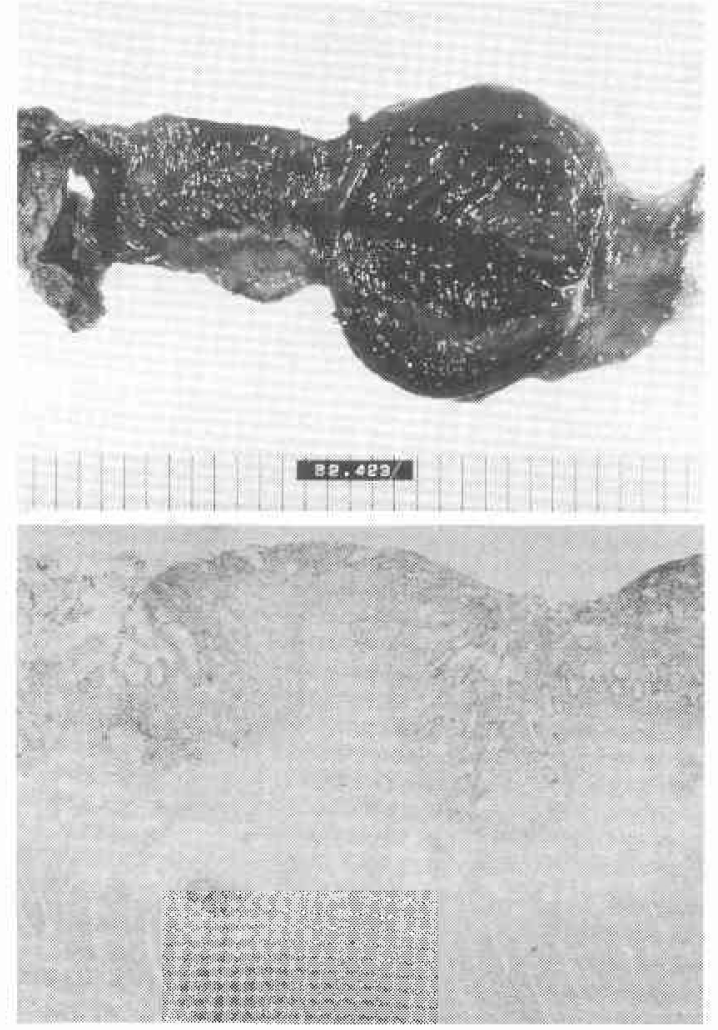

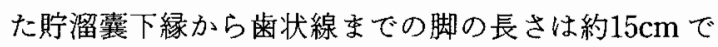
あった(写真 4 上). 組織所見では粘膜の萎縮, 一部び らんを認め粘膜下層は結合織増生により肥厚して扔り 炎症細胞浸潤を伴っていた（写真 4 下）.

再手術後の経過は順調であり昭和58年 3 月 27 日無事 退院した。

\section{III. 考 察}

偽膜性腸炎は主として，抗生剂投与後に，Clostridium difficile の毒素により起こることが知られて いるが1), 時には手術後にる発症することがある213).

今回われわれが経験した症例は，大腸全摘兼貯溜囊 付回腸肛門吻合術術後に発症したが，その直接の原因 は貯溜囊付加による腸内容停滞であると考觉られた。 すなわち術前および術後の抗生剂投与および大腸全摘 に上る腸内細菌叢变動に加兄, 貯溜囊内減王管抜去が 引き金となって貯溜囊内の貯溜液増加, 内圧六進に上 り C. difficileの異常増殖に起因したものと推察され た。入院時および前処置後の細菌叢の検索はなされて いないが, 炎症性腸疾患には sulfasalazine など投与の 
有無にかかわらず高率に C. difficile が検出されるこ と,なかには 9 カ月以上も持続するという報告もあ $\eta^{4)}$, 今回の症例でも術前から C. difficile が増加して いた可能性は否定できない。いずれにせよ今回の偽膜 性腸炎は, 内視鏡および生検組織所見から特に貯溜囊 内に強く認められたが, さらに口側の回腸にも炎症が 扣よんでいたことから貯溜霊焱あるいは回腸炎ともい らことができよう。

大腸全摘後の回腸炎は1951年 Warren and Mckittrick らが, 回腸瘦の約半数に ileostomy dysfunction が起きたことを報告5), Goligher は次のよ らに説明している 回腸㾇では突出部の浆膜炎から環状の線維化となり, その結果狭窄をさたすために始めは機械的腸閉塞の臨 床症状を呈するが，次第に機能的腸閉塞を惹起して 1 日量2 3lにも拉よぶ多量の水様性の腸液の排泄がみ られる。ささらに進行すると閉塞した回腸瘦の近位側に 回腸炎を起こし多数の小さな潰瘍がでさ穿孔をきたす こともあるとしている。しかし，1952年 Brooke ${ }^{7)}$, Turnbull ら ${ }^{8)}$ により eversionとした回腸瘦が行われ て以来, このような ileostomy dysfunctionは激減し た. その後 Kockが, continent ileostomy を考案した が，合併症として14例の non-specific ileitis を報告し ている9).これを Bonello は mucosal enteritis と呼び 発生率は13〜 43\%, 原因は貯溜霊造設により, functional blind loop となったため二次的な嫌気性菌の 増殖をきたしたためでその対策は, drainage と Metronidazole 投与が有効であることを指摘した ${ }^{10)}$. 種々の形の, 賍溜囊を置いた時の回腸肛門吻合の際に は loop ileostomy が付加されるが11)，その場合でる同 様の回腸炎あるいは眝溜囊炎が起こると考えられ る12).今回われわれの経験した偽膜性腸炎は, その発生 機序, 炎症の部位などからこれらの回腸炎と同じ病態 である可能性を強く示唆するすのであると考觉られ た。現在なでかかる重篤な合併症を起こした報告はな いが13), 貯溜震を設置する際にはこのような合併症を 常に念頭に和く必要がある。すななわち, その原因が腸 内容の停滞, 腸管内圧の上昇, あるいは予防的抗生剂 投与による腸管毒素産生菌の異常増殖であり診断は内 視鏡拉よび生検組織検查, さらに菌体同定, 毒素の証 明によらねばならない，その対策は十分な drainage とVancomycin, Metronidazole など感受性のある抗 生剂投与である。 また予防策として貯溜襄および吻合 部の maturation が完成するまで diverting ileostomy
による十分な減圧と安静をはかり functional blindloop とならない術式の選択が重要と考号られる。

\section{IV, 結 語}

1. 潰瘍性大腸炎に対する大腸全摘兼貯溜霊付回腸 䀴門吻合術術後に偽膜性腸资の発生をみた。

2. その発生機序, 炎症の部位などから, 貯溜囊炎と 同様の病態であると考えられた。

$$
\text { 文献 }
$$

1) Bartlett JG, Chang T, Talor NS et al: Colitis induced by clostridium difficile. Rev Infect Dis $1: 370-379, \quad 1978$

2) Rosenberg JM, Walker M, Welch JP et al: Clostridium difficile colitis in surgical patients. Am J Surg 147: 486--491, 1984

3) Keighley MRB, Alexander-Williams J, Burdon DW : Diarrhea and pseudomebronus colitis after gastrointestinal operations. Lancet 2: 1165-1167, 1978

4) Gorbach SL : Bacterial etiology of imflammatory bowel disease. Edited by Rachmilewitz D: Inflammatory Bowel disease, Developments In Gastroenterology. Vol. 3, London, Martinus Nijhoff, 1982, p 96-109

5) Warren R, Mckittrichk LS: Ileostomy for ulurative colitis. Surg Gyencol Obstet $93: 555$ $-567,1951$

6) Goligher JC: Surgery of the anus rectum and colon. Fourth edition. London, Bailliere Tindall, 1980 , p 734-735

7) Brooke BN: The management of an ileostomy including its complication. Lancet $11: 102$ $-104,1952$

8) Turnbull RB: Management of the Ileostomy. Am J Surg 86:617-624, 1953

9) Kock NG: Present status of the continent ileostomy: Surgical revision of the malfunctioning ileostomy. Dis Colon Rectum 19:200 $-206,1976$

10) Bonello JC: Mucosal enteritis. Dis Colon Rectum $24: 37-41,1981$

11) Martin LW, Lecoutre C, Schubert WK: Total colectomy and mucosal proctectomy with preservation of continence in ulcerative colitis. Ann Surg 186: 477-480, 1977

12) Taylor BM, Cranley B, Kelly KA et al: A clinicophysiological comparison of ileal pouchanal and straight ileoanal anastomosis. Ann Surg 198: 162-168, 1983

13) Schwartz SI : Annual overview, Year book of surgery, Chicago, Year book medical publishers, 1982, p 29-30 